\title{
16 \\ PLACE ATTACHMENT THEORY
}

\author{
Goksenin Inalhan, Eunhwa Yang, and Clara Weber*
}

\section{Background}

Place attachment has consistently been used to describe the phenomenon whereby people form emotional bonds to physical environments (e.g., Altman \& Low; 1992; Giuliani \& Feldman, 1993; Hidalgo \& Hernandez, 2001; Lewicka, 2005, 2010; Low \& Altman, 1992), despite the high variability of conceptualisations of place attachment across various disciplines of the social sciences (e.g., Lewicka, 2011b). Indicative of this variability is the range of labels that has been used to refer to the emotional bond between person and place, such as place attachment, rootedness, sense of place, and urban attachment (Hernández, Hidalgo, \& Ruiz, 2014). Due to the interdisciplinary nature of the subject, various epistemological and theoretical influences have been drawn on, leading to disagreement on how to define, conceptualise, and assess place attachment (e.g., Giuliani, 2003; Hernández et al., 2014; Lewicka, 2011a, 2011b; Patterson \& Williams, 2005; Scannell \& Gifford, 2010; Turton, 2016). For example, definitions of place attachment vary by the focus; either the focus is on the quality of the people-place bond (e.g., Altman \& Low, 1992; Low \& Altman, 1992), on the outcome associated with those bonds (e.g., state of psychological well-being, Giuliani \& Feldman, 1993; psychological and behavioural investment, e.g., Hummon, 1992), or on related constructs, such as place identity (e.g., Moore \& Graefe, 1994; Speller, 1996). As a result, no accepted overarching theoretical framework has been agreed on to date (Lewicka, 2011b; Turton, 2016).

Regardless of theoretical disagreements, the significance of the research on people-place bonds becomes apparent by its popularity in various social science disciplines and its application in numerous research contexts, such as 'social housing policy' (Manzo \& Perkins, 2006), neighbourhood design (Hester, 1984; Romice \& Uzzell, 2005), health and well-being (Bogdan, Rioux, \& Negovan, 2012; Wilson, DeJoy, Vandenberg, Richardson, \& Mcgrath, 2004), natural resource management (Kil, Holland, Stein, \& Ko, 2012; Lee \& Shen, 2013), tourism (Cui \& Ryan, 2011), regional planning (Kruger, 2008), and pro-environmental engagement (Devine-Wright, 2011; Jones, Orr, \& Eiser, 2011; Scannell \& Gifford, 2010; Turton, 2016, p. 20; Vaske \& Kobrin, 2001).

Several models of people-place relationships have been put forward, including the 'structural alternative model' (Gerson, Stueve, \& Fischer, 1977), the 'model of place dependence' (Stokols \& Shumaker, 1981), and the 'place identity model' (Proshansky, 1978). Based on limited empirical

*Corresponding author: weec@zhaw.ch 
tests, these models seek to provide a framework for how people develop ties to places. Based on a recent systematic review on the phenomenon's definitional ambiguity, place attachment has been presented as a multidimensional construct where affect is central to the relationship between people and place but which also incorporates cognitive and behavioural components (Turton, 2016). This view is relatively consistent with a recent theoretical advancement made by Scannell and Gifford (2010), who proposed the person-process-place (PPP) model, a tripartite framework of place attachment. The PPP framework attempts to organise the various conceptualisations of place attachment and identifies three distinct but interrelated dimensions: (1) the person dimension, (2) the psychological process dimension, and (3) the place dimension.

1 The person dimension differentiates between individual- and group-determined meanings of place.

2 The psychological process dimension differentiates between components that are involved in the process of being attached. These components are affect (emotion), (proximity-maintaining) behaviour, and cognition (thoughts).

3 The place dimension differentiates between the physical and socially bound characteristics of a place, contributing to the people-place bond.

Although the tripartite framework captures contributing variables in the attachment process, the saliency of variables may depend upon the scale and type of environment (e.g., Lewicka, 2011a, 2011b; Scannell \& Gifford, 2010). For example, city neighbourhoods (e.g., Bonaiuto, Aiello, Perugini, Bonnes, \& Ercolani, 1999) involve markedly different variables to studies of recreational areas (e.g., Kyle, Graefe, Manning, \& Bacon, 2004). Hence, variables that are salient in one type of setting may not be relevant in another type of setting: predictors cannot be treated as universally important to the attachment process (Turton, 2016). Therefore, the authors suggest that place attachment should not be considered as a generalisable phenomenon but should be contextualised (Turton, 2016).

\section{Applicability to workplace studies}

Understanding people's affective (emotion), cognitive (attitude), and behavioural reactions to place loss should inform prevalent organisational change management strategies (e.g., Harrison, Wheeler, \& Whitehead, 2004). Stakeholders in the workplace and the building industry should be aware of the impact workplace change can have on workers who may feel threatened and resistant to changes in the workplace (e.g., Fried, 2000; Inalhan, 2009; Manzo \& Perkins, 2006). Given that facility managers, designers, and planners have a significant responsibility for workers' psychological well-being, redesign and relocation processes should be undertaken in a manner informed by principles of workplace attachment research.

\subsection{Workplace attachment models}

The concept of workplace attachment is a recent one that has gained popularity in workplace research over the last few decades. Workplace attachment has been the subject of several studies that have examined workplace attachment associations with various socio-environmental and psychosocial variables (see Scrima, Rioux, \& Guarnaccia, 2019). Workplace attachment has been broadly defined as the emotional bond between a person and the physical work environment(s) of their associated organisation (e.g., Milligan, 1998, 2003a, 2003b; Rioux, 2006). Three theoretical models of workplace attachment have been acknowledged in the 
literature to date: (1) a unidimensional model of workplace attachment by Rioux (2006), (2) a transfer of the PPP model to the workplace (Ardalan, 2019; Grady, Grady, McCreesh, \& Noakes, 2020; Inalhan, 2009), and (3) a model by Inalhan (2009), which emphasises place loss and resulting emotion, attitudes, and behaviours relevant for workplace change processes.

\subsubsection{The unidimensional model of workplace attachment}

Rioux's (2006) model of workplace attachment is grounded in Shumaker and Taylor's (1983) unidimensional understanding of place attachment. As such, the emphasis lies in the affective component of the person-work environment relationship. Consequently, the derived measure, the Workplace Attachment Scale (WAS)/Echelle d'Attachement au lieu de travail (ÉALT), is a one-dimensional, seven-item scale based on the Neighborhood Attachment Scale by Bonnes, Bonaiuto, Aiello, Perugini, and Ercolani (1997). ${ }^{1}$ In their book, Manzo and Devine-Wright (2014) also highlight this approach as being quantitative because it relies on the Likert scale. Several studies (Le Roy \& Rioux, 2012; Rioux \& Pignault, 2013b; Velasco \& Rioux, 2010) have found that employees who are more attached to their workplace are more satisfied, show a lower tendency to leave their jobs, and improve their job performance compared with those who are less attached (Dinç, 2007).

\subsubsection{The PPP model in a workplace context}

The PPP model proposes a three-dimensional person-process-place organising framework that structures the varied definitions in the place attachment literature (Scannell \& Gifford, 2010, 2014). This framework is instructive in explaining workplace attachment as a multidimensional concept involving person, psychological process, and place dimensions (see Figure 16.1).

(1) The person dimension: Who is attached? To what extent is the attachment based on individually and collectively held meanings? In the workplace, place attachment occurs at both the individual (employee) and group levels (working groups), and although definitions of the term tend to emphasise one over the other, the two may overlap (Ardalan, 2019). At the individual level, it involves the personal connections that one has to the workplace. Place attachment is stronger for settings that evoke personal memories, and this type of place attachment is thought to contribute to a stable sense of self (Ardalan, 2019; Scannell \& Gifford, 2014). At the group level, attachment is comprised of the symbolic meanings of a place that are shared among working group members (Ardalan, 2019; Scannell \& Gifford, 2014). This kind of attachment has been described as a community process in which groups become attached to areas wherein they

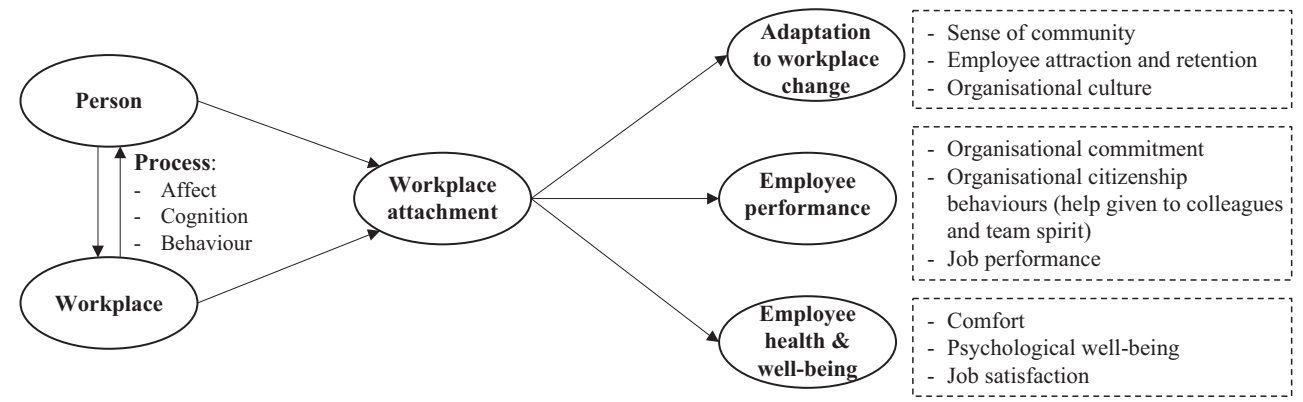

Figure 16.1 A framework of workplace attachment: person, place, process, and desired outcomes 
may practice, and thus preserve their organisational culture (Ardalan, 2019) (see also Chapter 12 on organisational culture theory). Culture links members to place through shared historical experiences, values, and symbols. Therefore, in workplace studies, the group and individual levels of place attachment are not entirely independent (Ardalan, 2019).

(2) The psychological process dimension: How are affect, cognition, and behaviour manifested in the attachment? This dimension concerns the way that individuals and groups relate to a workplace and the nature of the psychological interactions that occur in the work environments that are important to them. The three psychological aspects of place attachment are affect, cognition, and behaviour.

Workplace attachment as affect: The central role of affect in person-place bonding at work is an emotional investment in a place or feelings of pride and a general sense of well-being. Some evidence that attachment to a place is grounded in emotion comes from the literature on displacement when individuals must leave their places, such as in the event of an office relocation (e.g., individual employees or a full office relocation; Ardalan, 2019).

Workplace attachment as cognition: The memories, beliefs, meaning, and knowledge that individuals associate with their central settings make them personally important in workplaces. Place attachment as cognition involves the construction of, and bonding to, place meaning (see also Chapter 8 Social Constructionism Theory), as well as the cognitions that facilitate closeness to a place.

Workplace attachment as behaviour: Place attachment behaviours are not necessarily territorial, although the two may overlap, given that place use is an element of both. Territoriality is based on ownership, control of space, and the regulation of access to self, but attachment to places is an affective, proximity-maintaining bond that can be expressed without an underlying purpose of control (Manzo \& Devine-Wright, 2014).

(3) The place dimension: This dimension concerns the object of the attachment: the place itself and its characteristics. What is it about the place that instils a sense of attachment? It should be stressed that both physical and social characteristics of place influence the overall bond and that the spatial level should be considered when measuring place attachment.

Physical characteristics of place: Certain physical features, such as density, proximity, and the presence of amenities and other social arenas influence these interactions (see also Chapter 21 Space Syntax).

Social characteristics of place: When the attachment is directed towards others who live in the place rather than to aspects of the place itself, it is considered to be a socially based place bond because it is sometimes compared to, or conflated with, the sense of community (Inalhan, 2013). Furthermore, research gives some indication of the predictors of workplace attachment. Dinç (2007) found correlational evidence suggesting that atmospheric qualities and aesthetics (e.g., attractive, beautiful, and peaceful space), as well as functional qualities (e.g., room size and adequacy of the fit-out for work tasks), predict workplace attachment in personalised private offices. Interaction effects between environmental qualities, personalisation, and attachment are likely (Laurence, 2013). Of note, the ability to personalise one's workspace and having a private office are related to workplace design, management, and policy. Personalised enclosed offices have become less common with more organisations implementing open-plan offices or activity-based workplaces. Considerations of spatial efficiency, employee communication, and collaboration have prompted these innovations, although the benefits are frequently disputed. 


\subsubsection{The workplace attachment-and-disruption model}

Inalhan's (2009) workplace attachment model is grounded in Brown and Perkins's (1992) understanding of place attachment. Brown and Perkins (1992) postulate that place attachment only becomes apparent when place separation or place loss takes place. To investigate workers' reactions to workplace changes, Inalhan's (2009) workplace attachment model utilises Brown and Perkins's (1992) four attachment-and-disruption reaction patterns:

Phase 1 captures the development of attachment to the workplace environment.

Phase 2 captures the (work)place loss.

Phase 3 captures coping with lost attachment.

Phase 4 captures the development of attachment to a new workplace environment.

It has been postulated that the stage of coping with place loss (Phase 3) is challenging for both individual employees and management in terms of duration and identifying useful coping/recon ciliation strategies (Brown \& Perkins, 1992; Inalhan, 2009). In this sense, it has been suggested that the quality of attachment (Phase 1) is indicative of the severity of negative affect and attitudes experienced in Phase 2 and the variability in required coping/reconciliation strategies to handle place loss experienced in Phase 3 (Brown \& Perkins, 1992; Inalhan, 2009). With regard to the antecedents of successful coping (individual) and reconciliation (organisation) strategies in prior phases, Nicholson (1990) outlines establishing conditions that can support states of readiness for change.

\subsection{Desired outcomes of workplace attachment}

Place attachment can be thought of as both a process (i.e., reasons for attachment) and a product/ outcome (i.e., feeling attached; Giuliani, 2003). It is clear from the literature review that the concept can be operationalised in both ways. As a process, place attachment is the appropriation of space via involvement with the local area. It is a continuous, dynamic process. As a product, place attachment is an emotional bond with a specific place. The experience of feeling attached and belonging to a place can serve three desired outcomes of place attachment in workplace design and management:

1 adaptation to workplace change,

2 employee performance, and

3 employee well-being (see Figure 16.1).

\subsubsection{Adaptation to workplace change}

Even though recent interest in affect in workplace has been intense, opportunities and challenges remain on the emotional significance of the physical environment for employees (Inalhan, 2006, 2009).

The increased diversity and variety of working practices, work locations, and types of workplaces bring out key dilemmas to resolve. As the choices increase with regard to where and how people can work, the social component of the office grows in importance. Therefore, the future demands a higher level of facility management skills to evaluate the effectiveness of the workplace to support organisation strategies and individuals. Although workplace redesign and relocation have been used as a catalyst by many organisations to introduce myriad elements of 
organisational change, little thought has been given to the ways such changes may be viewed by the employees and the employee workspace attachment (Inalhan, 2006). The symbolism attached to place is a powerful force that works against locational flexibility. It is argued that many organisations have failed to implement new workplaces due to overwhelming employee resistance to change (Stegmeier, 2008).

Inalhan and Finch (2004) suggest that the physical environment could be used as a way to increase an employee's sense of attachment to the workplace. Good workspace design should seek to maintain those characteristics that are familiar and meaningful to employees; at the same time, it should constantly contribute to improving their attachment to the workplace (Ujang \& Zakariya, 2015). Therefore, the study of place attachment in the workplace environment contributes to developing and sustaining the attraction and the meaning of office settings. The degree to which a particular environment satisfies the needs and goals of an employee determines their judgment of its quality, and this judgment regulates the attachment to a place (Dinç, 2007; Stokols \& Shumaker, 1981; Zenker \& Rütter, 2014). Thus, workspace attachment is a consequence of the personal interactions between employees and their organisational environment (Milligan, 1998; Scrima, 2015). When a place provides the resources required for goal attainment (e.g., survival and security, temporal or personal continuity, etc.) and the use of those resources is frequent, attachment occurs (Inalhan \& Finch, 2004, 2012; Stokols \& Shumaker, 1981).

\subsubsection{Employee performance and organisational commitment}

Velasco and Rioux (2010) found a positive relationship between attachment to the workplace and affective commitment. According to the authors, employees who are emotionally attached to their workplace are more likely to develop a positive emotional connection to their organisation. Rioux and Pavalache-Ilie (2013) found that workplace attachment is a good predictor of two dimensions of organisational citizenship behaviours: 'help given to colleagues' and 'team spirit'. Specifically, the authors argue that the more employees are attached to the workplace, the more they will show citizenship behaviours towards their colleagues and contribute to the proper functioning of the team. In addition, employees attached to their workplace will show higher levels of job satisfaction than their colleagues with a low level of attachment (Rioux \& Pignault, 2013a, 2013b).

\subsubsection{Employee well-being and job satisfaction}

Workplace attachment is considered to be an important aspect of quality of work life (e.g., Scrima, Moffat, \& Rioux, 2016) because of its diverse impact on individual and worker-related outcomes such as worker well-being (e.g., Rioux, 2005, 2006), satisfaction (e.g., Scrima et al., 2019), comfort (c.f., Rioux, 2017), perception of team spirit and helping behaviour (Rioux \& Pavalache-Ilie, 2013), and employee retention (Rioux, 2006, 2011).

\section{Methodology/research approach}

\subsection{Employing mixed methods in place attachment research}

Combining quantitative and qualitative methods in place attachment research is critical to understand a phenomenon and its story. Quantitative methods can find 'how much' (Lewicka, 2011 b, p. 222) the importance of the relationship between people and places is, and qualitative 
methods can discover 'what the places mean to people' (Turton, 2016, p. 29). Thus, a mixedmethods approach provides analytical strengths from each method in a study, allowing researchers to uncover the full story of research problems (Creswell, 2015). Quantitative methods allow researchers to investigate the statistical significance of the relationship between people and places; inferential statistics provide the benefit of using a sample (a subset of the entire target population) to generalise the research findings to the target population. Qualitative methods can then determine why such relationships occur by providing details and context; additional factors that are not included in quantitative methods can be found through qualitative methods (Turton, 2016).

In studies of residential environments, quantitative methods have been used more extensively than qualitative methods. However, even in a quantitative study with a survey method, researchers often include interviews to add context to explain the results of the survey (Turton, 2016, p. 30). In qualitative residential studies, place attachment can provide important insights, such as how attachment changes over time (Lewicka, 2011b), the importance of social ties (Aiello, Barrat, Cattuto, Ruffo, \& Schifanella, 2010; Rollero \& De Piccoli, 2010), and the importance of matching environment with one's preference (Feldman, 1996; Twigger-Ross \& Uzzell, 1996). Specifically, Livingston, Bailey, and Kearns's (2008) qualitative study suggests that individual perception of welcoming and friendly neighbours is associated with higher residential place attachment. During in-depth semi-structured interviews, residents have reported higher residential place attachment when neighbourhood improvements occurred over time (Twigger-Ross \& Uzzell, 1996). Likewise, social, environmental, and economic aspects of residential areas can be better understood through a mixed-methods approach. Quantitative and qualitative methods can compensate for each other. Qualitative methods can answer 'why' and 'how' questions related to the findings of quantitative methods, and together, they can provide a more comprehensive understanding of a research problem.

\subsection{Potential moderators of workplace attachment}

In her review of the evidence, Turton (2016) indicates that length of residence is one of the most reliable predictors of place attachment in a residential context (see, for example, Bailey, Kearns, \& Livingston, 2012; Lewicka, 2008, 2010, 2011a; Williams et al., 2010). However, in her own work Turton (2016) observes that the effect of length of residence on attachment may be moderated by other factors; namely, social cohesion and type of environment. These factors may also be relevant to workplace attachment. Social cohesion is positively related to residential place attachment (Turton, 2016). Extrapolating from this evidence, spending more time in a workplace and participating to a greater extent in the workplace community may lead to greater social connections and greater attachment. Turton (2016) also found that length of residence was only a positive and significant predictor of place attachment in more urbanised environments, whereas social cohesion was a consistent predictor across different types of environments, including those that are more rural. In the context of attachment to workplace settings, research should not neglect the role of social connectedness in informing attachment relationships.

Future research should investigate the influence of organisational commitment by introducing other attitudes, such as job involvement and job satisfaction, along with the attachment to the workplace. This endeavour should involve an examination of their contribution and their respective roles in achieving organisational citizenship behaviours. It would also be interesting to conduct studies incorporating other dimensions from environmental psychology that could help enrich the work on understanding organisational citizenship behaviours.

The studies of attachment to the workplace so far have taken the relational approach (focusing on Bowlby's theory), the organisational approach (based on the organisational commitment 
model; Allen \& Meyer, 1990), and the environmental approach (focusing on place attachment as an emotional connection between an individual and a given place). However, very few studies to date have analysed the possible overlaps between these three approaches, although several studies have highlighted the relationship between affective commitment and workplace attachment (Velasco \& Rioux, 2010), between affective commitment and attachment style in the workplace (Neustadt, Chamorro-Premuzic, \& Furnham, 2011), and between workplace attachment and attachment style in the workplace (Scrima, 2014).

There are widespread variations in the definitions and functions ascribed to place attachment; they suggest that place attachment is a set of related phenomena rather than a singular phenomenon (Harris, 1998; Low \& Altman, 1992). Many researchers use the terms attachment, territoriality, and satisfaction with the workplace interchangeably without defining these concepts. There is a confusion regarding whether place attachment can be differentiated from other person-place terms such as territoriality and satisfaction with the place. Some researchers (Stokols \& Altman, 1987) have theorised that the concepts are intertwined, possibly with attachment either subsuming or being subsumed by the other two. Giuliani and Feldman (1993) suggest that a fruitful research direction would be to consider the plurality of emotional bonds with a place, by emphasising the distinctions between affective bonds and operationalising their specific effects.

\section{Limitations}

Certain characteristics of the previous works make it evident that place attachment studies have focused almost exclusively on home environments and neighbourhoods, while work environments have been neglected. The drive for undertaking workplace research comes from the fact that while the speed of change in work environments is much higher than in residential environments, there is a disparity in knowledge. Scant empirical work has been carried out using the qualitative methods, and little consensus has been reached in the area of operationalising the concept of place attachment. There is a pressing need for an effective conceptual approach that can be applied to facilities management (Inalhan, 2006).

Place attachment can be thought of as both a process (being an experience) and an outcome (being a product of an experience). The existing theory on 'place attachment' is incomplete and may not be applicable in all types of work environments.

Scrima (2015) examines the convergent discriminant validity of three scales: the Workplace Attachment Scale, the Adult Attachment Style in the Workplace Scale, and the Affective Commitment Scale. These three forms of emotional attachment to a specific place, to colleagues, and to the organisation seem to have a positive effect on quality of life at work. The discrimination between these three constructs may help researchers create functional models, explain employees' behaviour in the workplace, and enable human resource managers to design comfortable and customised spaces. Such measures may improve the quality of relationships between employees, enabling them to get to know and share values, opinions, and views of their organisation, thereby contributing to better workplace relationships and improved performance (Scrima, 2014). Specifically, these three levels of emotional attachment to the workplace, to colleagues, and to the organisation seem to be important resources for improving the quality of work life.

\section{Theory relevance to practice}

All of these studies underline the importance of attachment to the workplace in human resource management. Based on these theoretical contributions, human resource managers could 
implement organisational interventions geared towards employees' comfort, with the ultimate goal of developing commitment, encouraging organisational citizenship behaviours, and thereby increasing the performance of workers. Place attachments held by employees to the physical site of an organisation go unrecognised by the management involved in transition processes (Milligan, 1998, 2003a, 2003b). Ignoring the emotional charge given by these employees has the potential to undermine adaptation to workplace changes, employee performance, and employee health and well-being.

A complex relationship exists between workplace attachment and positive organisational behaviours like organisational 'civism' and organisational commitment. The ethical behaviour at work holds a privileged position in the preoccupations of organisations: civic organisational behaviour is highly valued. Workplace attachment and organisational commitment have proven to be strong predictors of organisational citizenship behaviour (Rioux \& Pavalache-Ilie, 2013) - a good reason for managers to stimulate the development of workspace appropriation (PavalacheIlie, 2016).

Scrima (2015) suggests that allowing employees to customise their office would increase attachment at work (Dinç, 2007). Specific training could be offered to improve the quality of relationships between colleagues with the aim of increasing confidence and improving communication (Ronen \& Mikulincer, 2012). Finally, involvement in organisational life could increase the bond between the employee and the organisation. The strong link between workplace attachment and adult attachment style should suggest to human resource (HR) practitioners the possibility to activate a virtuous cycle via organisational development practices aimed at improving employee attitude towards their established workplace. These practices, therefore, are of potential importance for influencing the sense of belonging to the work environments and this, in turn, may influence employees' health and well-being.

Personalisation of a workspace is usually possible when employees have designated workstations. Unassigned seating/hoteling systems are more evident in open-plan and activity-based offices, where increased space utilisation is important. While the office of the future requires designers and facility managers to think in terms of space and time rather than about desks and chairs, employees still continue to act upon the old person-place metaphor (Nutt \& McLennan, 2000). How do people develop a sense of place attachment in the 'hot swappable' work environment? How can modern workplaces be examined in the context of workplace attachment? Are there different degrees of place attachment according to spatial types (i.e., assigned enclosed offices, assigned workstation in an open area, unassigned workstation in an open area, kitchen, lounge, or overall attachment to the workplace as a whole)? In the era of the mobile worker, can place attachment continue to play its role as a pivotal source of identity and social cohesion?

Many organisations refer to 'the death of the office' as the COVID-19 pandemic leaves offices around the world empty, with many observers asking what the point of them was anyway (Nixey, 2020). While change and innovation can be uppermost in the minds of organisations today, they still struggle to implement it. For a sustainable future, workplace studies should address several questions:

1 The creative knowledge worker as a mobile person - does high mobility change the modes of identification of creative knowledge workers? Do workers develop new hybrid identification patterns in relation to places, jobs, and social roles? How can we create workplaces where every voice matters, everyone thrives and finds meaning, and change and innovation happen naturally (Di Masso et al., 2019; Nadler, 2014)? It is important to understand how creative knowledge workers orientate in physical and social space: do they still develop a routine of orientation in social and physical space? What do these people do 
while travelling? How do they perceive and use the transit time and transit spaces (third places) between their various places (Oldenburg, 1989)?

2 The creative knowledge worker as a locating person - how do such workers appropriate new places to make them a part of their own life? Do they develop specific routines to appropriate new places? How do they become members of local communities and cultural contexts abroad? To which scale do they feel they belong? Are places equally important, or are there certain hierarchies at play for creative knowledge production (Hirst, 2011; Nadler, 2014)?

3 The creative knowledge worker in relation to places - places not only influence creative knowledge workers and their lives, but these workers also reciprocally influence the places in which they live. What does the dialectic of physical absence and presence then mean to the places themselves? What do people significantly lack and long for in the workplace (Nadler, 2014)?

\section{Further reading}

- Fried, M. (1963). Grieving for a lost home. In L. J. Duhl (Ed.), The urban condition people and policy in the metropolis (pp. 124-152). New York: Basic Books.

- Giuliani, M. V. (1991). Towards an analysis of mental representation of attachment to the home. Journal of Architectural Planning Research, 8(2), 133-146. Retrieved from www.jstor. org/stable/43029028

- Sennett, R. (1999). Corrosion of character: Personal consequences of work in the new capitalism. New York: W.W. Norton Publications.

- Steele, F. (1981). Sense of place. Boston, MA: CBI Publishing.

- Sundstrom, E. (1986). Workplaces: The psychology of the physical environment in offices and factories. New York: Cambridge University Press.

\section{Note}

1 Although the scale has been used extensively with workers in different settings such as workplace staff (e.g., Rioux \& Pignault, 2013b; Scrima et al., 2016), hospital staff (Velasco \& Rioux, 2010) and school staff (Rioux \& Pignault, 2013a), it has limitations, which are indicated in the methods section.

\section{References}

Aiello, L. M., Barrat, A., Cattuto, C., Ruffo, G., \& Schifanella, R. (2010). Link creation and profile alignment in the aNobii social network. 2010 IEEE Second International Conference on Social Computing, Minneapolis, MN, pp. 249-256.

Allen, N. J., \& Meyer, J. P. (1990). The measurement and antecedents of affective, continuance and normative commitment to the organization. Journal of Occupational Psychology, 63(1), 1-18. https://doi. org/10.1111/j.2044-8325.1990.tb00506.x

Altman, I., \& Low, S. M. (Eds.). (1992). Place attachment. New York: Plenum.

Ardalan, K. (2019). Equity home bias in international finance: A place-attachment perspective. New York: Routledge.

Bailey, N., Kearns, A., \& Livingston, M. (2012). Place attachment in deprived neighbourhoods: The impacts of population turnover and social mix. Housing Studies, 27(2), 208-231. https://doi.org/10.10 80/02673037.2012.632620

Bogdan, C., Rioux, L., \& Negovan, V. (2012). Place attachment, proactive coping and well-being in a university environment. Procedia - Social and Behavioral Sciences, 33, 865-869. https://doi.org/10.1016/j. sbspro.2012.01.245 
Bonaiuto, M., Aiello, A., Perugini, M., Bonnes, M., \& Ercolani, A. P. (1999). Multidimensional perception of residential environment quality and neighbourhood attachment in the urban environment. Journal of Environmental Psychology, 19(4), 331-352. https://doi.org/10.1006/jevp.1999.0138

Bonnes, M., Bonaiuto, M., Aiello, A., Perugini, \& M., Ercolani, A. P. (1997). A transactional perspective on residential satisfaction. In C. Després \& D. Piché (Eds.), Housing surveys. Advances in theory and methods (pp. 75-99). Quebec: Centre de recherche en aménagement et développement, Université de Laval.

Brown, B., \& Perkins, D. D. (1992). Disruptions in place attachment In I. Altman \& S. Low (Eds.), Place attachment (pp. 279-304). New York: Plenum.

Creswell, J. W. (2015). A concise introduction to mixed methods research. Thousand Oaks, CA: Sage.

Cui, X., \& Ryan, C. (2011). Perceptions of place, modernity and the impacts of tourism: Differences among rural and urban residents of Ankang, China: A likelihood ratio analysis. Tourism Management, 32(3), 604-615. https://doi.org/10.1016/j.tourman.2010.05.012

Devine-Wright, P. (2011). From backyards to places: Public engagement and the emplacement of renewable energy technologies. In P. Devine-Wright (Ed.), Renewable energy and the public: From NIMBY to participation (pp. 577-574). London: Earthscan.

Di Masso, A., Williams, D. R., Raymond, C. M., Buchecker, M., Degenhardt, B., Devine-Wright, P., . . \& \& von Wirth, T. (2019). Between fixities and flows: Navigating place attachments in an increasingly mobile World. Journal of Environmental Psychology, 61, 125-133. https://doi.org/10.1016/j.jenvp.2019.01.006

Dinç, P. (2007). Spatial and behavioral variables that affect "emotional attachment" of users: A multidimensional approach for private offices. Gazi University Journal of Science, 20(2), 41-50.

Feldman, R. M. (1996). Constancy and change in attachments to types of settlements. Environment and Behaviour, 28(4), 419-445. https://doi.org/10.1177/0013916596284001

Fried, M. (2000). Continuities and discontinuities of place. Journal of Environmental Psychology, 20(3), 193205. https://doi.org/10.1006/jevp.1999.0154

Gerson, K., Stueve, A., \& Fischer, C. S. (1977). Attachment to place. In C. S. Fisher, R. M. Jackson, C. A. Stueve, K. Gerson, L. M. Jones, \& M. Baldassare (Eds.), Network and places: Social relations in the urban setting (pp. 139-161). New York: Free Press.

Giuliani, M. V. (2003). Theory of attachment and place attachment. In M. Bonnes, T. Lee, \& M. Bonaiuto (Eds.), Psychological theories for environmental issues (pp. 137-170). Farnham: Ashgate.

Giuliani, M. V., \& Feldman, R. (1993). Place attachment in a developmental and cultural context. Journal of Environmental Psychology, 13(3), 267-274. https://doi.org/10.1016/S0272-4944(05)80179-3

Grady, J., Grady, V., McCreesh, P., \& Noakes, I. (2020). Workplace attachments: Managing beneath the surface. New York: Routledge.

Harris, J. (1998). Real estate and the future. In J. Worthington (Ed.), Reinventing the workplace (pp. 50-60). Oxford: Architectural Press.

Harrison, A., Wheeler, P., \& Whitehead, C. (Eds.). (2004). The distributed workplace: Sustainable work environments. London: Spon Press.

Hernández, B., Hidalgo, M. C., \& Ruiz, C. (2014). Theoretical and methodological aspects of research on place attachment. In L. C. Manzo \& P. Devine-Wright (Eds.), Place attachment: Advances in theory, methods and applications (pp. 125-137). New York: Routledge.

Hester, R. T., Jr. (1984). Planning neighborhood space with people. New York: Van Nostrand Reinhold.

Hidalgo, M. C., \& Hernandez, B. (2001). Place attachment: Conceptual and empirical questions. Journal of Environmental Psychology, 21(3), 273-281. https://doi.org/10.1006/jevp.2001.0221

Hirst, A. (2011). Settlers, vagrants and mutual indifference: Unintended consequences of hot-desking. Journal of Organizational Change Management, 24(6), 767-788. https://doi.org/10.1108/09534811111175742

Hummon, D. M. (1992). Community attachment: Local sentiment and sense of place. In I. Altman \& S. M. Low (Eds.), Place attachment (pp. 253-278). New York: Plenum.

Inalhan, G. (2006). The role of place attachment on employees' resistance to change in workplace accommodation projects [Unpublished doctoral dissertation]. Reading, UK: Reading University.

Inalhan, G. (2009). Attachments: The unrecognised link between employees and their workplace (in change management projects). Journal of Corporate Real Estate, 11(1), 17-37. https://doi.org/10.1108/14630010 910940534

Inalhan, G. (2013). Quitter le confort du familier - L'attachement social au lieu de travail [Leaving the comfort of the familiar-social attachment to workplace]. In L. Rioux, J. Le Roy, L. Rubens, \& J. Le Conte (Eds.), Le confort au travail: Que nous apprend la psychologie environnementale? [Comfort in the workplace: What does environmental psychology teach us?] (pp. 174-216). Quebec: Les Presses de L'Université Laval. 
Inalhan, G., \& Finch, E. (2004). Place attachment and sense of belonging. Facilities, 22(5/6), 120-128. https://doi.org/10.1108/02632770410540333

Inalhan, G., \& Finch, E. (2012). Change and attachment to place. In E. Finch (Ed.), Facilities change management (pp. 155-174). Honoken, NJ: Wiley-Blackwell Publishing.

Jones, C. R., Orr, B. J., \& Eiser, J. R. (2011). When is enough, enough? Identifying predictors of capacity estimates for onshore wind-power development in a region of the UK. Energy Policy, 39(8), 4563-4577. https://doi.org/10.1016/j.enpol.2011.04.044

Kil, N. K., Holland, S. M., Stein, T. V., \& Ko, Y. J. (2012). Place attachment as a mediator of the relationship between nature-based recreation benefits and future visit intentions. Journal of Sustainable Tourism, 20(4), 603-626. https://doi.org/10.1080/09669582.2011.610508

Kruger, L. E. (2008). An introduction to place-based planning. In J. O. Farnum \& L. E. Kruger (Eds.), Place-based planning: Innovation and applications from four western forests. General Technical Report PNWGTR-741 (pp. 1-6). Portland, OR: USDA Forest Service, Pacific Northwest Research Station.

Kyle, G., Graefe, A., Manning, R., \& Bacon, J. (2004). Effects of place attachment on users' perceptions of social and environmental conditions in a natural setting. Journal of Environmental Psychology, 24(2), 213-225. https://doi.org/10.1016/j.jenvp.2003.12.006

Laurence, J. (2013). "Hunkering down or hunkering away?" The effect of community ethnic diversity on residents' social networks. Journal of Elections, Public Opinion and Parties, 23(3), 255-278. https://doi.org/ 10.1080/17457289.2013.808641

Lee, T. H., \& Shen, Y. L. (2013). The influence of leisure involvement and place attachment on destination loyalty: Evidence from recreationists walking their dogs in urban parks. Journal of Environmental Psychology, 33, 76-85. https://doi.org/10.1016/j.jenvp.2012.11.002

Le Roy, J., \& Rioux, L. (2012). The mediating role of workplace attachment in the relationship between organizational commitment and organizational citizenship behavior. Revue Internationale de Psychologie Sociale, 25(3), 211-233.

Lewicka, M. (2005). Ways to make people active: The role of place attachment, cultural capital, and neighborhood ties. Journal of Environmental Psychology, 25(4), 381-395. https://doi.org/10.1016/j. jenvp.2005.10.004

Lewicka, M. (2008). Place attachment, place identity, and place memory: Restoring the forgotten city past. Journal of Environmental Psychology, 28(3), 209-231. https://doi.org/10.1016/j.jenvp.2008.02.001

Lewicka, M. (2010). What makes neighborhood different from home and city? Effects of place scale on place attachment. Journal of Environmental Psychology, 30(1), 35-51. https://doi.org/10.1016/j. jenvp.2009.05.004

Lewicka, M. (2011a). On the varieties of people's relationships with places: Hummon's typology revisited. Environment and Behavior, 43(5), 676-709. https://doi.org/10.1177/0013916510364917

Lewicka, M. (2011b). Place attachment: How far have we come in the last 40 years? Journal of Environmental Psychology, 31(3), 207-230. https://doi.org/10.1016/j.jenvp.2010.10.001

Livingston, M., Bailey, N., \& Kearns, A. (2008). People's attachment to place: The influence of neighbourhood deprivation. Project report. York: Chartered Institute of Housing/Joseph Rowntree Foundation.

Low, S. M., \& Altman, I. (1992). Place attachment: A conceptual inquiry. In I. Altman \& S. M. Low (Eds.), Place attachment (pp. 1-12). New York: Plenum.

Manzo, L. C., \& Devine-Wright, P. (Eds.). (2014). Place attachment: Advances in theory, methods, and applications. New York: Routledge.

Manzo, L. C., \& Perkins, D. D. (2006). Finding common ground: The importance of place attachment to community participation and planning. Journal of Planning Literature, 20(4), 335-350. https://doi. org/10.1177/0885412205286160

Milligan, J. M. (1998). Interactional past and potential: The social construction of place attachment. Symbolic Interaction, 21(1), 1-33. https://doi.org/10.1525/si.1998.21.1.1

Milligan, J. M. (2003a). Loss of site: Organizational site moves as organizational deaths. International Journal of Sociology and Social Policy, 23(6-7), 115-152. https://doi.org/10.1108/01443330310790615

Milligan, J. M. (2003b). Displacement and identity discontinuity: The role of nostalgia in establishing new identity categories. Symbolic Interaction, 26(3), 381-403. https://doi.org/10.1525/si.2003.26.3.381

Moore, R. L., \& Graefe, A. R. (1994). Attachments to reaction settings: The case of rail-trail users. Leisure Sciences, 16(1), 17-31. https://doi.org/10.1080/01490409409513214

Nadler, R. (2014). Plug E play places: Lifeworlds of multilocal creative knowledge workers. Warsaw: De Gruyter Open. 


\section{Place attachment theory}

Neustadt, E. A., Chamorro-Premuzic, T., \& Furnham, A. (2011). Attachment at work and performance. Attachment \& Human Development, 13(5), 471-488. https://doi.org/10.1080/14616734.2011.602254

Nicholson, N. (1990). The transition cycle: Causes, outcomes, processes and forms. In S. Fisher \& C. L. Cooper (Eds.), On the move: The psychology of change and transition (pp. 83-108). Hoboken, NJ: John Wiley and Sons. https://doi.org/10.1002/smi.2460070413

Nixey, C. (2020, April 29). Work: Death of office. The Economist, 1843 Magazine. Retrieved from www.1843magazine.com/features/death-of-the-office

Nutt, B., \& McLennan, P. (2000). Facility management risk and opportunities. Oxford: Blackwell Science.

Oldenburg, R. (1989). The great good place: Cafes, coffee shops, bookstores, bars, hair salons and other hangouts at the heart of a community. New York: De Capo Press.

Patterson, M. E., \& Williams, D. R. (2005). Maintaining research traditions on place: Diversity of thought and scientific progress. Journal of Environmental Psychology, 25(4), 361-380. https://doi.org/10.1016/j. jenvp.2005.10.001

Pavalache-Ilie, M. (2016). Workspace appropriation and attachment. Bulletin of the Transilvania University of Braşov, 9(2), 27-34.

Proshansky, H. M. (1978). The city and self-identity. Environment and Behavior, 10(2), 147-169. https:// doi.org/10.1177/0013916578102002

Rioux, L. (2005). Approche psychosociale de l'attachement aux lieux de travail [Psychosocial approach to workplace attachment: A study carried out among hospital staff]. Working Paper No. 2005-2. Orléans: Université d'Orléans.

Rioux, L. (2006). Construction d'une échelle d'attachementau lieu de travail: Une démarche exploratoire [Construction of a scale of attachment to the workplace: An exploratory approach]. Revue Canadienne des Sciences du Comportement [Canadian Journal of Behavioural Science], 38(4), 325-336. https://doi. org/10.1037/cjbs2006018

Rioux, L. (2011). Workplace attachment and request for professional transfer: Study of a population of French employees. Bulletin of the Transylvania University of Braşov, 4(53), 91-96.

Rioux, L. (2017). Comfort at work: An indicator of quality of life at work. In G. Fleury-Bahi, E. Pol, \& O. Navarro (Eds.), Handbook of environmental psychology and quality of life research. International handbooks of quality-of-life (pp. 401-419). Basel: Springer. https://doi.org/10.1007/978-3-319-31416-7_22

Rioux, L., \& Pavalache-Ilie, M. (2013). Workplace attachment and organizational commitment: Are they predictors of organizational citizenship behavior? Annals of Alexandru Ioan Cuza University of Iasi, Psychology Series, 1, 5-18.

Rioux, L., \& Pignault, A. (2013a). Workplace attachment and meaning of work in a French secondary school. Spanish Journal of Psychology, 16(E23), 1-14. https://doi.org/10.1017/sjp.2013.42

Rioux, L., \& Pignault, A. (2013b). Apego al lugar de trabajo, apropiación del lugar de trabajo, y satisfacción laboral [Workplace attachment, workspace appropriation, and job satisfaction]. Psyecology: Revista Bilingüe de Psicología Ambiental - Bilingual Journal of Environmental Psychology, 4(1), 39-65. https://doi. org/10.1174/217119713805088342

Rollero, C., \& De Piccoli, N. (2010). Does place attachment affect social well-being? European Review of Applied Psychology, 60(4), 233-238. https://doi.org/10.1016/j.erap.2010.05.001

Romice, O., \& Uzzell, D. (2005). Community design studio: A collaboration of architects and psychologists. Centre for Education in the Built Environment Transactions, 2(1), 73-88. https://doi.org/10.11120/ $\operatorname{tran} .2005 .02010073$

Ronen, S., \& Mikulincer, M. (2012). Predicting employees' satisfaction and burnout from managers' attachment and caregiving orientations. European Journal of Work and Organizational Psychology, 21(6), 828-849. https://doi.org/10.1080/1359432X.2011.595561

Scannell, L., \& Gifford, R. (2010). Defining place attachment: A tripartite organizing framework. Journal of Environmental Psychology, 30(1), 1-10. https://doi.org/10.1016/j.jenvp.2009.09.006

Scannell, L., \& Gifford, R. (2014). The psychology of place attachment. In R. Gifford (Ed.), Environmental psychology: Principles and practice (5th ed., pp. 272-300). Victoria: Optimal Books.

Scrima, F. (2014). Comprendre l'attachement au travail pour agir sur le confort au travail [Understanding workplace attachment to act on comfort in the workplace]. Psychologie du Travail et des Organisations, 20(3), 295-310. https://doi.org/10.1016/S1420-2530(16)30031-0

Scrima, F. (2015). A three-factor structure of comfort in the workplace: An exploratory investigation. Paper presented at Groupe de Psychologie Environnementale de Paris Ouest Nanterre (GREPON), University of Paris Ouest Nanterre La Defense, Paris, France. 


\section{Inalhan, Yang, and Weber}

Scrima, F., Moffat, E., \& Rioux, L. (2016). The relationship between environmental satisfaction in the workplace and job satisfaction. A reciprocal longitudinal model. Psicologia Sociale, 11(2), 141-157.

Scrima, F., Rioux, L., \& Guarnaccia, C. (2019). A study of the relationship between workplace attachment and job satisfaction. TPM: Testing, Psychometrics, Methodology in Applied Psychology, 26(2), 209-220. https://doi.org/10.4473/TPM26.2.3

Shumaker, S. A., \& Taylor, R. B. (1983). Toward a clarification of people-place relationships: A model of attachment to place. In N. R. Feimer \& E. S. Geller (Eds.), Environmental psychology: Directions and perspectives (pp. 219-251). New York: Praeger.

Speller, G. (1996). Community in transition [Unpublished doctoral dissertation]. Guildford, UK: University of Surrey.

Stegmeier, D. (2008). Innovations in office design: The critical influence approach to effective work environments. Hoboken, NJ: John Wiley \& Sons.

Stokols, D., \& Altman, I. (Eds.). (1987). Handbook of environmental psychology (vols. 1 and 2). New York: Wiley.

Stokols, D., \& Shumaker, S. A. (1981). People in places: A transactional view of settings. In J. Harvey (Ed.), Cognition, social behaviour and environment (pp. 441-488). Hillsdale, NJ: Erlbaum.

Turton, C. J. (2016). Defining residential place attachment and exploring its contribution to community and personal environmental actions [Unpublished doctoral dissertation]. Guildford, UK: University of Surrey.

Twigger-Ross, C. L., \& Uzzell, D. L. (1996). Place and identity processes. Journal of Environmental Psychology, 16(3), 205-220. https://doi.org/10.1006/jevp.1996.0017

Ujang, N., \& Zakariya, K. (2015). Place attachment and the value of place in the life of the users. ProcediaSocial and Behavioral Sciences, 168(9), 373-380. https://doi.org/10.1016/j.sbspro.2014.10.243

Vaske, J. J., \& Kobrin, K. C. (2001). Place attachment and environmentally responsible behavior. The Journal of Environmental Education, 32(4), 16-21. https://doi.org/10.1080/00958960109598658

Velasco, L., \& Rioux, L. (2010). Enfoque psicosocial del “apego al lugar de trabajo”. Estudio realizado con personal hospitalario [Psychosocial approach to workplace attachment: A study carried out among hospital staff]. Estudios de Psicologia, 31(3), 309-323. https://doi.org/10.1174/021093910793154385

Williams, A., Kitchen, P., DeMiglio, L., Eyles, J., Newbold, B., \& Streiner, D. (2010). Sense of place in Hamilton, Ontario: Empirical results of a neighborhood-based survey. Urban Geography, 31(7), 905-931. https://doi.org/10.2747/0272-3638.31.7.905

Wilson, M. G., DeJoy, D. M., Vandenberg, R. J., Richardson, H. A., \& Mcgrath, A. L. (2004). Work characteristics and employee health and well-being: Test of a model of healthy work organization. Journal of Occupational and Organizational Psychology, 77, 565-588. https://doi.org/10.1348/0963179042596522

Zenker, S., \& Rütter, N. (2014). Is satisfaction the key? The role of citizen satisfaction, place attachment and place brand attitude on positive citizenship behavior. Cities, 38, 11-17. https://doi.org/10.1016/j. cities.2013.12.009 